\title{
THE STATUS OF THE CHILD AND THE CONFLICT OF LAWS
}

JOSEPH H. BEALE*

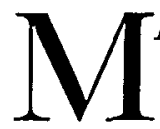

ANY experiments are now being conducted in the rearrangement of legal material. It is certainly true that the traditional arrangement leaves very much to be desired and has only the merit of being ancient and known to the Bar. Of course that is a great merit, but out of all the discussion and experiment something better ought to come.

I am offering as part of my share in this experimentation the treatment of the conflict of laws as it applies to a child, starting with his birth and going on until he is of riper years. This statement, as will be seen, runs into almost every branch of the law and has to be gathered together from as many sources. Whether when gathered together in this form it will be easier to master, to remember, and to investigate, it is impossible to guess. Without further preface, let us be legally present at the child's birth.

\section{PERSONAL QUALITY}

At the moment of separate life for the child he obtains legal personality; that is, he becomes a possible actor on the legal stage. ${ }^{x} \mathrm{He}$ is at once capable of acquiring rights, of suing and being sued, and of being represented in the administration of any property in which he might claim an interest.

This personality, like all personality, is limited to the state that creates it; but, fortunately for the infant, the law of every state in whose law he is likely to be interested endows him with personality from the moment of his birth. The incidents of personality, however, may vary in different states in which the infant may be. All states are likely to extend a right to freedom from physical aggression; not all would protect his personal dignity or his desire for privacy.

* Professor of Law, Harvard Law School.

' Adams v. Adams, 154 Mass. 290, 28 N.E. 260, I3 L.R.A. 275 (I891); In re Forney's Estate, 43 Nev. 227, 184 Pac. 206, I86 Pac. 678 (19I9); Olmsted v. Olmsted, rgo N.Y. 458,83 N.E. $5_{69}$, I23 Am. St. Rep. 585 (I908), aff'd. 2 x6 U.S. 386, 30 Sup. Ct. 292, 5o L.Ed. 530, 25 L.R.A. (N.S.) 1292 (I906), commented on 20 Harv. L. Rev. 400 (I907), 58 Univ. Pa. L. Rev. 558 (1910); Smith v. Thornton, 5 W.N.Cas. 372 (Pa. 1877 ); Hazzard's Estate, 8 W.N.Cas. 484 (Pa. I880); Matter of Look Wong, 4 U.S.Dist. Ct. Haw. 568 (I9I 5); In re Stirling, (I908) 2 Ch. 344; Shaw v. Gould, L.R. 3 H.L.C. 55 (1868). 
There might, however, be differences between states as to his being an infant at all. Thus the age of majority for men is in every common law state twenty-one, but in some states it is twenty-five; and the majority of a woman, in most of our States twenty-one, is eighteen in some States.

In France and most civil law states minority is regarded as a status, and, according to their ordinary doctrine, would be recognized and given effect to in every state. On this point, however, doctrine and decision have reached different results. In the case of a national twenty-three years old of another state in which the age of majority is twenty-five contracting in France where the age of majority is twenty-one, the courts will for one reason or another hold him responsible for his contract. This is in the teeth of doctrine, and apparently of the Code. Nevertheless, it is done by the courts. In the converse case, however, where the foreign young man is of age in his own state though not in France, he would again be held.

In common-law states minority is not regarded as a status but merely as a personal quality of the infant, which has this or that effect on various legal transactions. It is therefore regarded in these states as merely a qualification of the act to be governed by the law that governs the act. If a child is a minor by the law of his own state but of age in the state where he makes a contract, the contract will bind him. If a girl of twenty, of age in her former domicil, comes to a state where she is of age only on reaching twenty-one years, she will be treated not as an adult but as an infant for the purpose of acquiring a domicil in the second state. ${ }^{2}$

\section{FAMILIAL RELATIONS ${ }^{3}$}

\section{LEGITIMAACY}

The rights under this heading come into existence at the same time that the personal rights do, since the child's relations to his parents and the consequences that flow from these relations come at once. At birth, a child has a factual connection with a male parent and a female one. With each of these the factual relation may be legalized or it may not; or to put it in ordinary language, the child may be the legitimate child of either parent or of both, or he may be illegitimate as to both or one. The legal relation which is fixed at the birth involves first the relation to the father. The father is still as between him and the mother the legal head of the family, and his domicil has the first chance at making the child legitimate with respect to the father.

2 Beekman v. Beekman, 53 Fla. 858, 43 So. 923 (1907).

${ }^{3}$ I would much rather use the word domestic, which I am used to, than the word familial, which strikes me as both novel and cacophonous; but one must be modern at all costs. 
Thus, where one obtains a void divorce, and then marries again and has children, the marriage being polygamous and void, the children are (at least at common law) illegitimate, whether the person who obtained the divorce was domiciled in the state which granted it $^{4}$ or in another state. ${ }^{5}$ In Matter of Look Wong ${ }^{6}$ a man domiciled in Hawaii, where he had a wife, went to China and married another as permitted by the law of China. As the woman was domiciled in China, the marriage was probably valid. A son of the Chinese woman was not allowed admission to Hawaii as son of his Hawaiian father. It would seem that the law of Hawaii, the father's domicil, would not under these circumstances make the child the legitimate child of the father; but even if it did, the court might have refused to recognize the relation.

Usually the child of parents who are not legally married is illegitimate. There are, however, in several of the states of this country, statutes providing that the children of a void or annulled marriage, begotten before a decree of nullity, shall be legitimate. Where there was such a statute at the domicil of the father at the time of the child's birth, the child will be recognized everywhere as legitimate. ${ }^{7}$

It may be suggested that a state having no such statute might yet regard a child as legitimate although in fact the parents had not been married. The question is suggested by the leading case of Shaw v. Gould.$^{8}$ In that case an English woman secured a divorce in Scotland, which the Scotch court regarded as valid, and thereupon married a domiciled Scotchman. A child was born of this marriage who claimed property devised to "the child of" the mother. The English court, holding the Scotch divorce invalid, held that the child of the Scotch marriage was illegitimate. In so far as this is a decision that he was an illegitimate child of the mother, there can be no doubt of the soundness of the judgment, because, the mother being a domiciled English woman, the law of England must concur in creating a legitimate status between her and her child, and that law refused to do so. If the question had been as to the legitimacy of the child with reference to his father, it is submitted that the case would have

4 Olmsted v. Olmsted, rgo N.Y. 458,83 N.E. 569 , I 23 Am. St. Rep. 585 (Ig08), aff'd. 216 U.S. 396,30 Sup. Ct. 292, 50 L.Ed. 530, 25 L.R.A. (N.S.) I 292 (I 906 ), commented on 20 Harv. L. Rev. 400 (IgO7), 58 Univ. Pa. L. Rev. 558 (Igro).

5 Adams v. Adams, 54 Mass. 290, 28 N.E. 260, 13 L.R.A. 275 (r89r).

6 Matter of Look Wong, 4 U.S. Dist. Ct. Haw. 568 (rgr5).

7 Mund v. Rehaume, 5I Colo. I29, Ir 7 Pac. I59, Ann. Cas. Igr3A, I243 (I9Ir); Moore v. Saxton, go Conn. $6_{64}$, 96 Atl. 960 (I9I6) (bigamous); Eubanks v. Banks, 34 Ga. 407 (I866); Green v. Kelley, 228 Mass. 602, I 8 N.E. 235 (I9I 8) (bigamous); Lincecum v. Lincecum, 3 Mo. 401 (I834) (bigamous).

${ }^{8}$ Shaw v. Gould, L.R. 3 H.L.C. 55 (r868). 
been different. The father being domiciled in Scotland at the time of the child's birth, Scotch law would determine the status between the father and the child; and it seems that this law would have held the child legitimate and that it would have had power to do so in spite of the fact that the ground on which it would have done so was unsound; namely, that there was a valid marriage between the father and mother of the child. In a similar case the mother of a child had obtained a divorce in Dakota while resident there. The divorce would probably have been declared invalid outside that state. The woman then married a Dakota man, and the child was born. It was held that the child of the marriage, a legitimate child of both parents by the law of 'Dakota, was a legitimate child of the mother for purposes of succession. ${ }^{9}$

It sometimes happens that a child, apparently when born the illegitimate child of his father, may by a later event be legitimated from birth; for instance, by a recognition of paternity by the father, or by the marriage of the parents. Such a result of a subsequent act, effective from the beginning, must take effect as the performance of a condition on which legitimacy was from the beginning to take place. The father's domicil at the birth of the child, as has been seen, determines the child's legitimacy with respect to the father.

Legitimation after birth which relates back to the birth must be the result of a potential legitimacy created at the time of birth by the law of the state of the domicil of the parent concerned; since only such a potentially created status should be related back to the time of birth. Until the condition is fulfilled, the child is provisionally domiciled with the mother. The father's domicil, however, retains a potential hold on the child which may become actual upon the happening of the event.

Unless the law of the state of domicil of a parent at the moment of the child's birth provides for subsequent legitimation from birth, there can be no such retroactive legitimation. The possibility of legitimacy must exist from birth in order that the legitimation may relate back and affect from the beginning all transactions which involve the legitimacy.

The child may be legitimated from birth as child of the mother as well as of the father.

A typical example of legitimation from birth is legitimation by subsequent marriage of the parents. At the time of the birth, for instance, the law of the state of the father's domicil provides that an illegitimate child may be legitimated by the subsequent marriage of its parents. This means that that law, being the law that has power to do so, gives the child at

9 Re Hall, 6I App. Div. 266, 70 N.Y.S. 406 (1901). 
birth a potential legitimacy with regard to the father, but postpones to a later time, as the result of the performance of the condition (namely, marriage), the change from potential into actual legitimacy. Until the performance of the condition it is not possible to prove legitimacy and the relationship must be treated as illegitimate.

By the principles of the canon law the marriage of the parents of an illegitimate child at any time after the birth of the child resulted in legitimating it, ex post facto, from the moment of birth. This principle became part of the common law of Europe, and prevails generally in the law of European states. But, by another provision of European law, any effect of marriage must be governed by the law of the marriage; which in turn (except where this has been changed by modern codes substituting the law of the nation) is the law of the domicil of the parties at the time of the marriage.

When a question arises, therefore, of legitimating a child by a subsequent marriage, under the European law, it becomes a question of the domicil of the father both at the birth of the child and at the date of marriage. The domicil at birth must obviously make the child legitimate from birth; for if it refuses to do so there can be no possibility of accomplishing such a result; no other law could force the legitimacy from birth and therefore the domicil of the child upon the sovereign of the father's domicil. Furthermore, if a marriage can have no effect except such as is given it by the husband's domicil at the time, the concurrence of the law of his domicil alone can accomplish the result. This requirement of a concurrence of the law of two domicils is well brought out in a series of English cases, all looking to the law of some other European country to legitimate a child. If by the law of the father's domicil at birth and by the law of his domicil at marriage a child is legitimated by a subsequent marriage, the child is recognized as legitimated; but it is not legitimated if the father either at the time of the child's birth or at the time of his own marriage was domiciled in a country the law of which does not legitimate by subsequent marriage, though at the other of these times he was so domiciled; and of course, no matter what the domicil of the mother or the place of marriage, there can be no legitimation when the father is at all times domiciled in a state which does not permit legitimation. ${ }^{\text {ro }}$

Many of the American States have provisions by which the subsequent marriage of the parents of a natural born child legitimates the child. These States, having no trace of the civil law principle that the effect of marriage must be governed by the law which creates the marriage, present a much

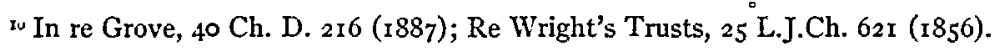


simpler question as to the effect of the marriage on legitimating the children. If the children are born with a conditional legitimacy, the performance of the condition will, it seems, of itself be sufficient to create the legitimate status. A child born at a time when his father was domiciled in a place where such a law prevailed, will therefore be legitimated by a subsequent marriage no matter what domicil his father may subsequently have acquired and no matter what law prevails in establishing marriage. ${ }^{\text {II }}$ In most American cases the question does not arise, since the domicil has been unchanged; and it is held simply that when the parties are domiciled at the birth of the child in a state that has such a law, the child becomes legitimate as a result of the marriage..$^{x_{2}}$ If legitimated by the proper law, the status will be everywhere recognized. ${ }^{x_{3}}$ But, on the other hand, if by the proper law the child was not so legitimated, it can be given no legitimate status in any other state where such a law prevailed. ${ }^{x_{4}}$ If the marriage by reason of which legitimacy is claimed is void, the marriage has no effect on the legitimacy of children previously born; $;^{\mathrm{x}}$ and the burden of proving the marriage valid is on the person who claims that legitimation has taken place. ${ }^{16}$

The law may give to an act other than marriage the effect of legitimating from birth; for instance, the recognition of the child. If the law of the state of domicil of either parent at the birth of the child provides for legitimating the child from birth by recognition of paternity after birth,

II Miller v. Miller, 9r N.Y. 3r5, 43 Am. St. Rep. 669 (I883).

I2 Caballero's Succession, 24 La. Ann. 573 (1872); Holloway v. Safe D. \& T. Co., I5I Md. 32I, I34 Atl. 497 (I926); Loring v. Thorndike, 5 All. 257 (Mass. I862); Dayton v. Adkisson, 45 N.J.Eq. 603,17 Atl. 964,4 L.R.A. 488 , 14 Am. St. Rep. 763 (r889); Stack v. Stack, 6 Den. 280 (N.Y. I887); Bates v. Virolet, 33 App. Div. 436, 53 N.Y.S. 893 (I898); Fowler v. Fowler I3I N.C. 6 69,42 S.E. 563 , 59 L.R.A. 3 I 7 (r902); Ives v. McNicoll, 59 Ohio St. 402,53 N.E. 60, 43 L.R.A. 772, 69 Am. St. Rep. 780 (1898); McCausland's Estate, 213 Pa. 189, 62 Atl. 780, I ro Am. St. Rep. 540 (Igo6); De Wolf v. Middleton, i8 R.I. 8Io, 26 Atl. 44, 3I Atl. 27, 3 I L.R.A. I46 (I893).

In Caballero's Succession, supra, the parents could not have been married at the father's domicil, Louisiana, because the mother was a woman of color; but by the law of Louisiana at the time of the child's birth a natural child was legitimated by subsequent marriage. The parties were legally married in Cuba, to which place the father's domicil had been changed. It was held that the child was legitimated.

${ }^{13}$ Miller v. Miller, 9r N.Y. 315, 43 Am. St. Rep. 669 (1883); Bates v. Virolet, 33 App. Div. 436, 53 N.Y.S. 893 ( 1898 ).

${ }_{14}$ Smith v. Kelly, 23 Miss. 167, 55 Am. Dec. 87 (1851).

${ }^{35}$ Matter of Look Wong, 4 U.S. Dist. Ct. Haw. 568 (I9r 5).

${ }^{16}$ Meekins v. Meekins, 169 Ark. 265, 275 S.W. 337, commented on 24 Mich. L. Rev. 650 (1925). 
the child becomes the legitimate child of that parent from birth if he or she subsequently recognizes the child while there domiciled.

In the case of Blythe v. Ayres, ${ }^{17}$ for instance, a California man had an illegitimate child in England by an English woman. Neither woman nor child was ever outside England; yet the child was legitimated from birth by the law of California. How could an act under the California law remove the child from its domicil in England and from the custody of its English mother without consent of the English law? The answer must involve a consideration of the situation at the birth of the child. At that time the child's status was in the control of the father's domicil. The lawgiver of that domicil may say through his law that the child is the legitimate child of the father, in which case the mother's domicil has no control of the child; or he may say, it is not the father's legitimate child, and then it gives up control of the child definitively. But in a country where the law permits legitimation by subsequent event, the lawgiver does neither of these things. He says, the child has the possibility of becoming legitimate; if certain acts are done in the future, he is so. The child is relinquished to the mother's domicil provisionally only, upon a condition which if it happens restores him at once to the father's domicil. To paraphrase an expression which Lord Mansfield used of bail, the father's domicil still holds a string attached to the child; it never gives up its connection with or control over the child. It may pull the string and get the child without the help of another law.

It may also be asked, is the child legitimated as to the mother by the law of the father's domicil only? A legitimation of a child from birth by subsequent marriage would affect its status from birth as to the father only, unless it had the same effect by the law of the mother's domicil at the birth. But since at marriage the mother takes the father's domicil as of the time of the marriage, the child legitimated by the marriage becomes the legitimate child of the mother from that time, if not from birth, since the law of the mother's new domicil so provides.

A sovereign of the domicil of the parties may legitimate a natural born child at any time and legitimacy will supervene from that moment. This may be done by a special act of legislation, as was, for instance, the practice in England. Such an act in the proper state must result in the creation of a legitimate status and this status should be recognized as existing in every state. ${ }^{18}$ It is true that this status is not always recognized as suff-

17 Blythe v. Ayres, 96 Cal. 532, 3x Pac. 91 5 (r892).

${ }^{28}$ Scott v. Key, II La. Ann. 232 (1856); Mund v. Rehaume, 5 I Colo. I 29, I 7 Pac. I 59, Ann. Cas. Igr3A, I 243 (IgrI). 
cient to make the party an heir to land in another state, but this is a matter of the law of inheritance rather than the law of legitimacy. ${ }^{x}$

The commoner method of legitimating a child after birth is by a statute which creates the legitimate relation as a result of the recognition or acknowledgment of the child. Such an acknowledgment can take effect only by the law of the domicil of the parent, and unless the parent with whom the legitimate relation is to be established is domiciled in a state which permits such an act, the legitimation is not accomplished. ${ }^{20}$ If the father is resident in the state which permits legitimation by recognition, though the mother and child are domiciled elsewhere, the legitimation is accomplished and should be recognized in every state..$^{2 \mathrm{I}}$ If the domicil of the father at the time of the act of recognition was in a state which did not legitimate, a later removal to a state which would have legitimated does not confer the status. ${ }^{22}$

It may be asked why, since a status is to be created between two persons, should the law of the domicil of each not need to be satisfied if the relation is to be created? The answer appears to be that the creation of the status is so obviously beneficial to the child that the consent of the child's domicil to the creation of the status and its co-operation in creating it is therefore tacitly but legally given. If the law of the parent's domicil therefore creates legitimacy, that of the domicil of the child does the same.

A relation less than legitimation, that of recognized natural child, may arise by the law of several European states between a parent and natural child. Such a relation must be created by the law of the domicil of the parties. ${ }^{23}$ There is no corresponding status at common law; and in a common law state, therefore, this status has no legal effect. ${ }^{24}$

Legitimacy once created by the proper law will everywhere be recog-

I9 Birtwhistle v. Vardill, 7 Cl. \& F. 895 (I840); Hood v. McGhehee, 237 U.S. 6II, 37 Sup. Ct. 7 I8 (IgI4). In some states, perhaps most, the rule is otherwise. Miller v. Miller, $9 \mathrm{I}$ N.Y. 315,43 Am. St. Rep. 669 ( 1883 ).

${ }^{20}$ In re Forney, 43 Nev. 227, I84 Pac. 206, I86 Pac. 678 (I9r9); Eddie v. Eddie, 8 N.D. 376, 79 N.W. 856,73 Am. St. Rep. 765 (r899).

- ${ }_{2 x}$ Pfeifer v. Pfeifer, 34 F. (2d) 690 (D.C. Okla. r929); Blythe v. Ayres, 96 Cal. 532, 3 I Pac. 9I5 (1892); Monson v. Palmer, 8 All. 55I (Mass. r864); Irving v. Ford, I83 Mass. 448, 67 N.E. 366,65 L.R.A. I77, 97 Am. St. Rep. 447 (r903). In Lingen v. Lingen, 45 Ala. 4 ro (I8 7 I), though the court denied this effect to the act of legitimation, the court was in fact following Doe v. Vardill on the question of inheritance.

${ }_{22}$ Eddie v. Eddie, 8 N.D. 376 , 79 N.W. 857, 73 Am. St. Rep. 765 ( 1899 ); Estate of Presley, II3 Okla. I60, 240 Pac. 89 (I925), commented on 24 Mich. L. Rev. 851 (1925).

${ }^{23}$ Fordham v. Marrero, 273 Fed. 6I (C.C.A. Ist x921); Atkinson v. Anderson, 2I Ch. D. roo (I882).

${ }^{24}$ Atkinson v. Anderson, 2I Ch. D. IOO (I882). 
nized, and the same effect be given to it as is given to the same status created in the state of forum, or in the state where the effect is to be found. Thus one legitimate by the proper law, though he would not be by the law of the situs of land, may inherit land.25 So a person legitimate by the proper law may take under the statute of distributions of a state by the law of which he would not be legitimate. ${ }^{26}$ A child legitimated by the proper law may take a legacy to a "child" of the parent with whom his legitimation has been established, ${ }^{27}$ or take as beneficiary under an insurance policy. ${ }^{28}$

Any state may of course refuse to recognize a foreign legitimacy as contrary to its policy. On sound principle there seems no reason for so refusing. ${ }^{29}$ Such refusal has no possible effect on the relations which resulted in the birth of the child. But in recent cases a federal court has refused to recognize the legitimacy of a foreign legitimate Chinese child on the ground that the child was born of a "secondary marriage," that is, a polygamous marriage..$^{30}$ This may perhaps be supported on the ground that the father was domiciled in the United States at the time of the birth of the child, ${ }^{3 x}$ but this does not clearly appear in the cases.

\section{CUSTODY}

The child is subject, from birth to majority, to the patria potestas of the parent who has the legal custody of him. Custody, that is, the possession and control of a child, may be predicated of anyone, parent, kin, or stranger, who has the legal right to such control. It is more commonly used, however, to designate the control exercised by a parent; and for the sake of clearness it is herein used to designate the control of a parent, and is not used in the case of a guardian. It will be noticed that the custodian's relation to the child is not created by the decree of custody; that relation is the relationship of parent to child. The relation of guardian to ward, however, is a relation newly created by the decree.

At common law, the father alone had a right to custody of the child, the

${ }_{25}$ McDeed v. McDeed, 67 Ill. 545 (1873); Holloway v. Safe D. \& T. Co., I5I Md. 32 I, I34 Atl. 497 (I926); McCausland's Estate, 213 Pa. I8g, 62 Atl. 780, rro Am. St. Rep. 540 (I906).

${ }^{26}$ Loring v. Thorndike, 5 All. 257 (Mass. I862); Scott v. Key, II La. Ann. 32 (1856); Re Goodman's Trusts, 17 Ch. D. 266 (188I); contra, Barnum v. Barnum, 42 Md. 25I (I875), which seems to be overruled by Holloway v. Safe D. \& T. Co., x 5 I Md. 321 , 34 Atl. 497 (Ig26).

${ }_{27}$ In re Andros, 24 Ch. D. 637 ( 1883 ).

${ }^{28}$ Mund v. Rehaume, $5^{x}$ Colo. 129 , Ir7 Pac. I59, Ann. Cas. I9r 3 A, I243 (I9ri).

${ }_{29}$ Moore v. Saxton, 90 Conn. 164, 96 Atl. 960 (1916).

${ }^{3 \circ} \mathrm{Ng}$ Suey Hi v. Weedin, 2I F. (2d) 80I (C.C.A. gth I927); Mason v. Tillinghast, $26 \mathrm{~F}$. (2d) 588 (C.C.A. Ist 1928).

31 This was apparently the case in Matter of Look Wong, 44 U.S. Dist. Ct. Haw. 568 (1915). 
mother under no circumstances having such a right during the father's life. But first in America, then later in England, the right of the father was limited; at first by depriving him of custody if he were unfit, afterwards by recognizing a right in the mother. The mother's right is usually confined to the case of divorce; but in several states statutes have been passed declaring the rights of the father and the mother to the custody of their children to be equal.

It is beyond the scope of this article to examine the law of the various states on this point. It is enough to say that without a divorce the custody of a child may be given to the mother if the father is found to be unfit. $^{32}$

Since custody of a child by one parent carries with it domicil and a domestic status, jurisdiction to give the child to one parent or the other depends in principle on the domicil of the child;33 and a state which is the temporary residence of the child, not the domicil, cannot confer the right to custody. ${ }^{34} A$ fortiori a decree for custody rendered in a state where the child is neither resident nor domiciled is void for lack of jurisdiction. ${ }^{35}$

Custody is usually awarded in a suit for divorce. If one party only is domiciled in the state which grants the divorce, and the child is outside the state at the domicil of the other parent, the custody cannot be awarded unless the non-resident parent appears. ${ }^{36}$ If both are domiciled in the state at the beginning of the divorce suit, the court has jurisdiction, it would seem, to award custody although one parent has changed the domicil of himself and the child pending the appeal; jurisdiction once having attached will not be divested. ${ }^{37}$ If after a divorce the party to whom custody was given moves with the child to another state, this would seem to give the second state jurisdiction over the custody, and to put an end to the

32 Bryant v. Dukehart, I06 Ore. 359, 210 Pac. 454 (r922); Com. v. Sage, 160 Pa. 399, 28 Atl. 863 (I894); White v. Bickford, I46 Tenn. 608, 244 S.W. 49, 26 A.L.R. I29 (1922).

33 The decision to the contrary in De la Montanya v. De la Montanya, II2 Cal. Ior, 44 Pac. 345, 32 L.R.A. 82, 53 Am. St. Rep. 165 (1896) must be regarded as unsound upon this point, and it is believed it would be disregarded even in California.

34 People v. Dewey, 23 Misc. 267, 50 N.Y.S. ror3 (I898); Leaning v. Gregory, roo Tex. 3ro, 99 S.E. 542, Io L.R.A. (N.S.) 690, I23 Am. St. Rep. 809 (1907).

35 Weber v. Redding, 200 Ind. 448, I6 3 N.E. 269 (r928); Sanders v. Sanders, 224 Mo. App. II07, 14 S.W. (2d) 458 (r929); Griffin v. Griffin, 95 Ore. 78, I87 Pac. 598 (r920).

${ }^{36}$ Weber v. Redding, 200 Ind. 448 , I6 6 N.E. 269 (I928); Sanders v. Sanders, 224 Mo. App IIO7, I4 S.W. (2d) $45^{8}$ (I929).

37 State v. Rhoades, 29 Wash. 6r, 69 Pac. 389 (I902). This seems to have been recognized in People v. Allen, I05 N.Y. 628, II N.E. I43 (I887), although the court said that the decree for custody was not conclusive, but a fact to be considered. This view of the force of the decree seems an untenable one on any consideration. 
jurisdiction of the first state $3^{38}$ for after the divorce each party may change domicil at will, and the child's domicil changes with that of the parent in whose custody he has been placed. In one case it was said that the removal of the parent with the child beyond the state "is not a taking of the child beyond the jurisdiction of the court in the sense that the court would thereby lose jurisdiction to change its order in the future should subsequent events require it. The jurisdiction of the court over the child will not be ousted thereby." ${ }_{39}$ But it is submitted that this language is not adapted to the case of parent and child, where the parent in custody of the child has full power over the child's domicil. It is applicable rather to a case of guardianship, where the guardian, deriving his whole power over the child from the act of the court, cannot, at least without the court's consent, change the child's domicil outside the state.

The fact that the parent to whom the award of custody would otherwise be made is likely to take the child into another state is not usually a ground for refusing to make the award..$^{\circ}$ Even if the child is to be taken into another country the award will be made, at least if it is a friendly country with a similar civilization, like England, ${ }^{4 \mathrm{x}}$ though it might be different if it were a barbarous country, or one with an alien civilization or religion $;^{42}$ and clearly a child's custody will not be awarded to a parent who is an alien enemy. ${ }^{43}$ Nevertheless, the court in awarding custody may order the parent not to remove the child from the state, ${ }^{44}$ though the case would have to be "a very extreme one indeed" to justify such interference with the natural and legal rights of a parent. ${ }^{45}$ If the court allows a child to be taken out of the state, it may require the parent to give a bond to

${ }^{38}$ Re Alderman, 157 N.C. 507,73 S.E. 126, 39 L.R.A. (N.S.) 988 (19II); Griffin v. Griffin, 95 Ore. 78, r87 Pac. 598 (1920); Barnes v. Lee, I28 Ore. 655, 275 Pac. 66r (1929); State v. Rhoades, 29 Wash. 61, 69 Pac. 389 (Ig02); Groves v. Barto, rog Wash. II2, I86 Pac. 300 (1919).

${ }^{39}$ Meredith v. Krauthoff, I9r Mo. App. 149,177 S.W. Irr2 (1915). A similar statement in Stetson v. Stetson, 80 Me. 483 , 15 Atl. 60 (1888), is subject to the same criticism.

$4^{40}$ Adams v. Adams, I Duv. I68 (Ky. 1864); Workman v. Workman, rgx Ky. I24, 229 S.W. 379 (I92r); Stetson v. Stetson, 80 Me. 482, 55 Atl. 60 (1888); Sanders v. Sanders, 224 Mo. App. 1 107, ${ }_{4}$ S.W. (2d) $45^{8}$ (I929); Re Means, 176 N.C. 307,97 S.E. 39 (Igr8); Barnes v. Long, 54 Ore. 548, I04 Pac. 296, 25 L.R.A. (N.S.) r72, 2 I Ann. Cas. 465 (I909); Ex parte Davidge, 72 S.C. 16 , 51 S.E. 269 (1905); Griffin v. Griffin, 18 Utah 98, 55 Pac. 85 (1898).

4 Wilson v. Mitchell, 48 Colo. 454, Ix I Pac. 21, 30 L.R.A. (N.S.) 507 (Igro); Re Bullen, $28 \mathrm{Kan} .78 \mathrm{x}$ ( $\mathrm{r} 882$ ).

$4^{2}$ Wilson v. Mitchell, 48 Colo. 454, I I I Pac. 2I, 30 L.R.A. (N.S.) 507 (rgro semble).

${ }_{43}$ Uhlig v. Uhlig, II 5 L.T.N.S. 647 (I9I7).

4 Miner v. Miner, I I Ill. 43 (I849).

45 Rallihan v. Motschmann, 179 Ky. 180 , 200 S.W. 358 (1918). 
return the child at the end of a fixed time, or on order of the court; ${ }^{46}$ but this will not usually be required. 47

The award of custody to the mother does not affect the obligation of the father in the state where the child is domiciled with the mother to support the child. $4^{8}$

When the custody of a child has been awarded to one parent by a court having jurisdiction so to do, the right of this parent will be recognized by other states. ${ }^{49}$ The facts upon which the award was based have become res judicata, and cannot be reëxamined in the second state..$^{\circ}$ But this estoppel extends only to conditions which existed at the time of the original decree; the second court may examine any facts which have-occurred since the original decree which throw light upon the fitness of the parents to have custody of the child. ${ }^{\mathrm{x}}$

If in the normal case, where the family is living together, the father dies, the custody automatically passes to the mother. But if the parents are living apart (whether divorced or not) and the custody has been awarded to one party, who dies, the case is not so clear. It has been held that if the custody has been given to the mother, it passes automatically to the father upon her death ${ }^{22}$ unless he is then found to be unfit..$^{53}$ So if the father dies and the mother remarries, she has been held entitled to the custody of the .

${ }^{46}$ Mattox v. Mattox, I29 Okla. 3or, 264 Pac. 898 (Ig28).

47 Parrish v. Parrish, II6 Va. 476, 82 S.E. II9, L.R.A. I9I5A, 576 (I9I4).

${ }^{8}$ Geary v. Geary, 102 Neb. 5 Ir, I67 N.W. 778 (19r8).

49 Burns v. Shappley, I6 Ala. App. 297, 77 So. 447 (I9r7); Ex parte Wenman, 33 Cal. App. 592, I65 Pac. I024 (I9I7); Church v. Church, 50 App. D. C. 237, 270 Fed. 359 (I92I); Hardin v. Hardin, I68 Ind. 352,81 N.E. 60 (r907); Wakefield v. Ives, 35 Iowa 238 (1852); State v. District Court, 46 Mont. 425 , I28 Pac. 580, Ann. Cas. rgr6B, 256 (rgr2); Hartley v. Blease, 99 S.C. 92,83 S.E. 99 I (r9ז4).

${ }^{\circ}$ Woodland v. Woodland, 153 Ga. 202, III S.E. 673 (I922); Re Leete, 205 Mo. App. 225, 223 S.W. 962 (r920); Dixon v. Dixon, 76 N.J. Eq. 364, 74 Atl. 995 (rgog); Griffin v. Griffin, 95 Ore. 78, I87 Pac. 598 (I920); Barnes v. Lee, I28 Ore. 655, 275 Pac. 66I (r929); Wilson v. Elliott, 96 Tex. 472, 43 S.W. 946, 97 Am. St. Rep. 928 (r903); Groves v. Barto, rog Wash. x x2, I86 Pac. 300 (19I9).

${ }_{51}$ Woodland v. Woodland, ${ }_{53}$ Ga. 202, Ix I S.E. 673 (r922); Griffin v. Griffin, 95 Ore. 78 , r87 Pac. 598 (r920); Barnes v. Lee, I28 Ore. 655, 275 Pac. 66I (I929); Wilson v. Elliott, 96 Tex. 472, 43 S.W. 946, 97 Am. St. Rep. 928 (r903); Kentzler v. Kentzler, 3 Wash. I66, 28 Pac. 370, 28 Am. St. Rep. 2I (I89I); Groves v. Barto, Iog Wash. II2, I86 Pac. 300 (Igrg).

${ }^{22}$ Stafford v. Stafford, 299 Ill. 438, r32 N.E. $45^{2}$ (r92I); Pinney v. Seelzen, 9r Kan. 407, I37 Pac. 987, Ann. Cas. r9r 5C, 649 (I9r4); Clarke v. Lyon, 82 Neb. 625, xr8 N.W. 472, 20 L.R.A. (N.S.) I 7 (Ig08); Ex parte Barnes, 54 Ore. 548, 104 Pac. 296, 26 L.R.A. (N.S.) I72, 2 I Ann. Cas. 465 (rgog).

53 Bryant v. Dukehart, 106 Ore. 359, 210 Pac. 454 (1922). 
child as against her second husband. ${ }^{54} \mathrm{~A}$ court hereafter dealing with this question of custody must take into account the opinion of Matter of Thorne. ${ }^{55}$ In this case the difficulty was raised in the court and the court was almost evenly divided in opinion. In that case the parents had been divorced before the death of the father, and the custody of the child had been given to the father. The father died and a guardian was appointed at the domicil of the father; the mother, however, claimed possession of the child. The majority of the court, Judge Pound writing the opinion, which was concurred in by Judges Cardozo, McLaughlin and Andrews, held that in spite of the divorce the domicil of the child shifted automatically to that of the mother at the father's death and that a guardian could not be appointed at the domicil of the late father. The minority of the court, Judge Lehmann, Chief Justice Hiscock and Judge Crane, took the opposite view, holding that the court at the domicil of the father had jurisdiction to appoint a guardian of the person, at least in a case like this where there had been a divorce of the parents.

It would appear more in accordance not merely with the general course of decisions, but also with convenience, to hold the minority right. Where the husband and wife are living together, the wife's domicil is the husband's and no difficulty can arise. Where they have been divorced, it would seem better to hold that the husband's domicil has the opportunity to decide whether a child shall be given to a guardian or to the mother, and that if the mother is to have possession of the child it should be only by order of the court of her late husband's domicil, or at least that she should not have such possession if the court of the late husband's domicil chooses to prevent her custody by the appointment of a guardian. If the parties are separated voluntarily or by fault of the husband without a divorce and without any custody of the child having been awarded to one party rather than the other, the law gives the custody of the child to that parent with whom the child actually lives; and it would seem, if the child has been living with the husband, that the guardian appointed at the husband's domicil would have the right to the child. The arguments of convenience are these: the child in this case is in the father's state, the mother's separate domicil may be at the other end of the world and it would be most inconvenient to have no final control over the child determined until the mother chooses to appear or can be found.

${ }^{54}$ Lamb v. Lamb, 7 Alaska 4 I4 (I926).

ss Matter of Thorne, 240 N.Y. 444, I48 N.E. 630 (r925), discussed in 26 Col. L. Rev. 104 (I926), 38 Harv. L. Rev. $39^{2}$ (I925). 


\section{GUARDIANSHIP}

The relation between guardian and ward is a domestic status, and the court of the domicil of the ward has jurisdiction to appoint the guardian of the ward's person. ${ }^{56}$ The guardian, as has been seen, is any one not a parent who has legal custody of a ward. The case is the same whether the ward is an infant or an insane person or other incompetent.

If the guardian appointed at the domicil of the ward applies for the custody of the child in another state, it will normally be granted to him..$^{57}$ But if the best interests of the child require it, the foreign guardian may be refused possession of the ward just as the father might be refused possession for the same reason if he were alive..$^{88}$

A temporary guardian may be appointed for an infant in a state where he is found, though he is not domiciled there..$^{59}$ Such a guardian will ordinarily not be recognized in another state; ${ }^{60}$ but in his own state he may be preferrred to the domiciliary guardian in case the interest of the child obviously requires such preference ${ }^{6 \mathbf{r}}$ and in the absence of any domiciliary. guardian, such a guardian would probably be preferred even in another state. ${ }^{62}$

A guardian of the person will not be appointed if the child is neither domiciled nor found within the state. ${ }^{63}$ As in the case of awarding custody,

${ }^{56}$ Shorter v. Williams, 74 Ga. 539 (1885); Succession of Vennard, 44 La. Ann. Io76, Ir So. 705 (I892); Butler v. Butler, 83 N.H. 4 I3, ${ }_{43}$ Atl. $47 \mathrm{I}$ (I928). A statement to the contrary in De la Montanya v. De la Montanya, II 2 Cal. I3I, 44 Pac. 345 (I896), must be regarded as unsound.

s7 McDowell v. Gould, 666 Ga. 670, I44 S.E. 206, (I928); Mahon v. People, 218 Ill. I7r, 75 N.E. 768 (I905); Grimes v. Butsch, I42 Ind. II3, 4r N.E. 328 (1895); Warren v. Hofer, $x_{3}$ Ind. 167 (1859, semble); Townsend v. Kendall, 4 Minn. $3^{\mathrm{r}} 5$, 77 Am. Dec. 534 (1860); Wells v. Andrews, 60 Miss. 373 (1882); Hanrahan v. Sears, 72 N.H. 7I, 54 Atl. 702 (I903); Com. v. Dryman, 15 W.N.Cas. 223 (Pa. I884); Nugent v. Vetzera, L.R. 2 Eq. 704 (I866).

$5^{8}$ Kelsey v. Green, 69 Conn. 29r, 37 Atl. 679, 38 L.R.A. 47 (r897); Taylor v. Jeter, 33 Ga. r95, 8I Am. Dec. 202 (1862); Woodworth v. Spring, 4 All. 32 I (Mass. I862); Re Rice, 42 Mich. 528, 4 N.W. 284 (I880); In re Stockman, 7 I Mich. I80, 38 N.W. 876 (I888); Townsend v. Kendall, 4 Minn. 3I5, 77 Am. Dec. 534 (I860, semble); Foster v. Alston, 6 How. 406 (Miss. I842); Hanrahan v. Sears, 72 N.H. 7x, 54 Atl. 702 ( 1903 , semble); Wood v. Wood, 5 Paige 596, 28 Am. Dec. 45 I (N.Y. I836); Jones v. Bowman, $r_{3}$ Wyo. 79, 77 Pac. 439, 69 L.R.A. 860 (rgo4).

59 People v. Dewey, 23 Misc. 267, 50 N.Y.S. 1013 (1898, semble).

${ }^{60}$ Powers v. Mortee, Ig Fed. Cas. No. II, 362, 4 Am. I. Reg. \& Rev. 427 (I855); Grimmett v. Witherington, I6 Ark. 377, 63 Am. Dec. 66 (1855); Shorter v. Williams, 74 Ga. 539 (1885); Succession of Vennard, 44 La. Ann. ro76, Ix So. 705 (1892).

6r Hartman v. Henry, 280 Mo. 478, 217 S.W. 987 (r920); Wilkin's Guardian, I46 Pa. 585, 23 Atl. 325 (r892); Jones v. Bowman, $x_{3}$ Wyo. 79, 77 Pac. 439, 69 L.R.A. 860 (Ig04).

62 In re Williams, 77 N.J. Eq. 478,77 Atl. 350,79 Atl. 686 (rgro).

63 In re Caruso's Guardianship, ror N.J. Eq. 215, I37 Atl. I54 (1927); Caruso v. Caruso, ror N.J. Eq. 350, I39 Atl. 802 (I927). And see Taylor's Estate, 9 Pa. Co. Ct. 122 (I89o). 
a guardian may be appointed who will be likely to take the ward outside the state. ${ }^{6}{ }_{4}$ The court may in its discretion require the guardian to give a bond to return the child. ${ }^{65}$ The case is different from that of custody; for a guardian, since he is not a parent (or natural guardian), cannot cause the child to be domiciled outside the state; and the court therefore continues in control of the status though the child is taken outside the state. ${ }^{66}$

A natural guardian will be recognized in every state as entitled to the child if there is no regularly appointed guardian at the domicil.

This seems to be the effect of the decision in In re Williams. ${ }^{67}$ There a father and mother abandoned their child, the mother consenting that the child be held in an orphanage in Rhode Island, which was the domicil. The orphanage placed the child in New Jersey with a person for six months with a view to his ultimate adoption. At the end of six months the person not being satisfactory to the orphanage, the latter applied to a New Jersey court to get the child back. The petition was granted on the ground that although the child's domicil was not in New Jersey, the state had power to deal with children actually resident in the state and the petitioner being in loco parentis had jurisdiction to get the child back.

${ }_{4}$ Perry v. Johnson, 53 Me. 4 or (I866); Butler v. Butler, 83 N.H. 4I3, r43 Atl. 47I (1928); Ex parte Martin, 2 Hill Eq. 7 I (I I S.C. Eq. I834).

(5 Watkins v. Rose, I 5 S.C. 370 , 105 S.E. 738 (Ig2r).

${ }^{66}$ An intimation to the contrary in Butler v. Butler, 83 N.H. $4{ }^{\mathrm{r}} 3$, I43 Atl. $47 \mathrm{r}$ (I928), seems unsound. The court erroneously treated the relation as one of custody, though the person appointed to control the child was an aunt.

${ }^{67}$ In re Williams, 77 N.J. Eq. 478, 77 Atl. 350, 79 Atl. 686 (I9ro). 